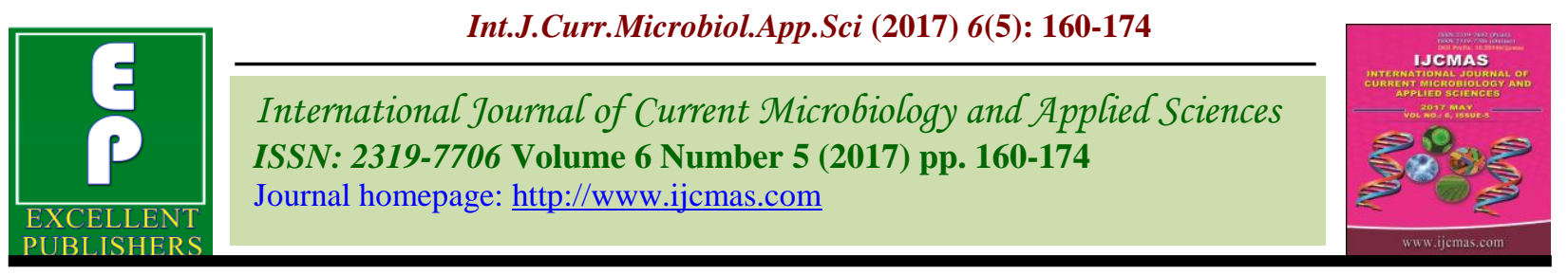

Original Research Article

https://doi.org/10.20546/ijcmas.2017.605.019

\title{
Gum Ghatti Based Edible Coating Emulsion with an Additive of Clove Oil Improves the Storage Life and Maintains the Quality of Papaya (Carica papaya L., cv. Madhu bindu)
}

\author{
Arpit V. Joshi*, Nilanjana S. Baraiya, Pinal B. Vyas and T.V. Ramana Rao \\ P.G. Department of Biosciences, Sardar Patel University, Vallabh Vidyanagar, \\ Anand 388120, Gujarat, India \\ *Corresponding author
}

\author{
A B S T R A C T
}

Keywords

Edible coating, Carica papaya $\mathrm{L}$, Postharvest technology, Gum ghatti, Clove oil, Shelf life.

Article Info

Accepted:

04 April 2017

Available Online:

10 May 2017
The perishable nature of papaya (Carica papaya L.) fruits is a major disadvantage of its transportation process to far places and storage in the market. Thus the current study has been undertaken with an objective of extending its shelf life with the edible coating comprised of gum ghatti $(1 \%, 2 \%$ and $3 \%)$ and clove oil $(0.1 \%)$. The quality characteristics of papaya were monitored at a regular interval of three days during their storage period at room temperature $\left(25 \pm 2{ }^{\circ} \mathrm{C}\right)$. Gum ghatti combined with the clove oil reduced the weight loss, decay percentage, accumulation of TSS and total sugars by diminishing the rate of respiration and metabolism in coated fruits. Moreover, the coated fruits enhanced the levels of phenolics, ascorbic acid and antioxidant activity in these fruits. The activities of cell wall modifying enzymes, polygalacturonase (PG) and cellulase, were reduced in the treated sets as compared to that of the control set. These results suggest that the coating of gum ghatti combined with clove oil delays the ripening and softening in papaya fruits, thereby extend their shelf life and improve their quality characteristics.

\section{Introduction}

Papaya (Carica papaya L.) is a popular and an economically important fruit of tropical and subtropical regions. As a human food, they are of excellent flavour and sweetness, and their nutritional value is high. It is a valuable source of antioxidants (vitamin $\mathrm{C}$, carotenes and flavonoids), minerals (calcium, potassium and magnesium) and fibre. Papaya will meet about $20 \%$ of an adult's daily folate needs, and about $75 \%$ of an adult's daily vitamin C needs (Brishti et al., 2013). Marketing of fresh papaya is a major problem because of its short post-harvest life, which causes high post-harvest losses (Jayathunge et al., 2011). Papaya fruits become soft quickly at room temperature after harvest. Thus a 2 to 3-day shelf life only can be expected (Archbold et al., 2003).

Edible coatings are eco-friendly and biodegradable technology that can be applied to food materials to control moisture transfer, gas exchange or oxidation processes. It is a novel technique to extend shelf-life and improve the quality characteristics of fruits (Park et al., 1999). Moreover, edible coatings have been emerging as a magnificent way to carry additives since they are able to maintain 
the effective concentration of the additives on fruit surfaces and reducing the effect of such chemicals on the overall acceptability of the fruit (Oms-Oliu et al., 2010). In view of above narrated post-harvest preservation problems of papaya and the potential of edible coating in improving the shelf life of perishable horticultural produce an attempt has been made to evaluate the efficacy of the coating of gum ghatti with an additive of clove oil. The reasons for selecting these compounds are as follows:

Gum ghatti used in the present study is an extracellular polysaccharide obtained from Anoggeissus latifolia (Combretaceae, Myrtales). It is a natural, and an anionic product. Sugar composition of gum ghatti is galactose, arabinose, mannose, xylose, rhamnose, glucuronic acid. Use of gum ghatti is mainly due to its admirable emulsification properties (Castellani et al., 2010). The gum ghatti coating layer does not crack when dried and provides a uniform or identical layer on the fruit surface. It provides higher viscosity than gum arabic.

Clove oil is obtained from the Syzygium aromaticum (S. aromaticum) (synonym: Eugenia cariophylata), generally known as clove. Clove has attracted the attention due to their potent antioxidant and antimicrobial activities among the other spices. Clove is a major source of flavonoids, hydroxybenzoic acids, hydroxycinamic acids and hydroxyphenylpropenes. Clove has a great potential of radical scavenger and as a commercial source of poly-phenols (Bamdad et al., 2006). The clove oil has antimicrobial, antifungal, antiseptic, antiviral, aphrodisiac, and analeptic properties.

Therefore, the present study has been undertaken to examine the efficiency of gum ghatti and clove oil to improve the postharvest quality and shelf life of papaya fruits.

\section{Materials and Methods}

\section{Materials}

The Papaya fruits were collected at their mature stage from an agricultural farm of Tranod village located near Kunjrav village in Anand district of Gujarat state, India. To obtain film forming dispersions, gum ghatti and clove oil of Hi-media brand, Mumbai (India) were procured through local chemical suppliers of Anand town, Gujarat.

\section{Preparation of film forming emulsion}

Gum ghatti coating was prepared by dispersing different concentrations of gum ghatti powder $(1,2$ and $3 \%, \mathrm{w} / \mathrm{v})$ in distilled water or warm distilled water with continuous stirring under magnetic stirrer till it solubilized, and then filtered it. Thereafter, clove oil of $0.1 \%(\mathrm{v} / \mathrm{v})$ concentration was added to gum ghatti solution, and it was further stirred using a magnetic stirrer for 30 min to achieve an emulsion of gum ghatti and clove oil.

\section{Application of coatings}

The freshly harvested papaya fruits were immediately transported to the laboratory, and they were sorted for their uniform shape, size, and maturity and with no signs of mechanical damage or microbial decay. Papayas were cleaned by washing them in water and then immersed in $2 \%$ solution of sodium hypochlorite $(\mathrm{NaOCl})$ for 10 minutes and airdried at room temperature. These fruits were grouped into four sets having six units in each set. Of these, four sets were kept as experimental sets, while the $5^{\text {th }}$ was treated as control. And subsequently they were subjected to the following edible coating treatments by dipping for 2-3 min: T1 (Gum ghatti $1 \%$ + Clove oil $0.1 \%$ ), T2 (Gum ghatti $2 \%+$ Clove oil $0.1 \%$ ), T3 (Gum ghatti 3\% + 
Clove oil $0.1 \%$ ), T4 (Gum ghatti $2 \%$ ) and control C (Treated with water). Following these treatments, all the sets were kept to air dry at room temperature and stored at $25 \pm 2^{\circ} \mathrm{C}$ room temperature. These stored fruits were subjected to their physicochemical and biochemical analyses at 0, 3, 6 and 9 days of storage, and their quality and shelf life were evaluated by analysing the following parameters at 0 day and thereafter at regular interval of 3 days.

\section{Weight loss percentage (WLP)}

The Weight loss percentage (WLP) of papaya fruits samples was calculated by considering the difference between initial weight and final weight of fruits divided by their initial weight.

\section{Storage life}

The shelf life was calculated by counting the days required for papaya fruits to attain the last stage of ripening, but up to the stage when they remained still usable, fit for consumption, or saleable (Mondal, 2000).

\section{pH and Total soluble solid (TSS)}

One gm of papaya fruit tissue was crushed with water by motor-pastel and this homogenised sample was centrifuged and then used for analysing the $\mathrm{pH}$. The $\mathrm{pH}$ of the fruit samples was determined using the method described by AOAC (1994). The TSS was measured by putting a few drops of sample on the prism of the refractometer (Atago CO., Tokyo, Japan).

\section{Biochemical analysis of papaya}

\section{Total soluble sugars}

Extraction and estimation of soluble sugars were carried out by following the phenolsulphuric acid method described by Sadasivam and Manickam (1992).

\section{Pigment estimation}

Extraction and estimation of total chlorophylls and total carotenoids and lycopene were carried out by following the method of Wang et al., (2007).

\section{Total phenols}

Estimation of total phenols was performed by using the method cited by Thimmaiah (1999).

\section{Total ascorbic acid}

The quantitative analysis of ascorbic acid was carried by following the method of Roe et al., (1954).

\section{Total antioxidant activity}

The total DPPH activity was measured by using the method described by SanchezMoreno et al., (2003).

\section{Enzyme extraction and assay}

A $2 \mathrm{~g}$ sample of papaya fruit tissue was crushed in Tris-HCL (20 mM, pH 7.0) containing cysteine-HCL $(20 \mathrm{mM})$, EDTA (20 $\mathrm{mM})$ and Triton X-100 (0.05\%). Then this crushed homogenised sample was centrifuged at $15000 \mathrm{xg}$ for $30 \mathrm{~min}$ at $4^{\circ} \mathrm{C}$ in the refrigerated centrifuge. The clear supernatant was taken and used for the enzymatic assays (Lohani et al., 2004). The protein concentration was measured using the Lowry's method (Lowary et al., 1951).

\section{Assay of Polygalacturonase (PG)}

Polygalacturonase activity was assayed according to the method described by Pathak and Sanwal (1998). The reaction mixture contained $0.2 \mathrm{ml}$ sodium acetate buffer (200 $\mathrm{mM}, \mathrm{pH} 4.5), 0.1 \mathrm{ml} \mathrm{NaCl}(200 \mathrm{mM})$, and 0.3 $\mathrm{ml}$ Polygalacturonic Acid (PGA, 1\% aqueous 
solution adjusted to $\mathrm{pH} 4.5$ ) and $0.05 \mathrm{ml}$ of enzyme extract in a total volume of $1.0 \mathrm{ml}$. The mixture was incubated at $37^{\circ} \mathrm{C}$ for $1 \mathrm{hr}$. followed by the addition of $3 \mathrm{ml}$ DNS (3,5Dinitro Salicylic acid). The reaction mixture was stopped by heating the mixture in boiling water bath (BWB) for $5 \mathrm{~min}$ and added $1 \mathrm{ml}$ Sodium Potassium Tartrate (SPT, 40\%). In control tubes, the substrate was added after the heat treatment. The formation of reducing groups was estimated against $D$-galacturonic acid as the standard, after measuring the absorbance at $540 \mathrm{~nm}$.

\section{Assay of cellulase}

Cellulase activity was assayed by the method described by Pathak and Sanwal (1998) cited by Lohani et al., (2004). The reaction mixture contained $0.25 \mathrm{ml}$ sodium acetate buffer (100 $\mathrm{mM}, \mathrm{pH}$ 5.0), $0.5 \mathrm{ml}$ Carboxy Methyl Cellulase (CMC, 1.5\%), and $0.25 \mathrm{ml}$ of enzyme extract in total volume of $1.0 \mathrm{ml}$. The mixture was incubated at $37^{\circ} \mathrm{C}$ for $16 \mathrm{hr}$. followed by the addition of $3 \mathrm{ml}$ DNS (3, 5Dinitro Salicylic acid). The reaction mixture was stopped by heating the mixture in boiling water bath (BWB) for $5 \mathrm{~min}$ and adds $1 \mathrm{ml}$ Sodium Potassium Tartrate (SPT, 40\%). In control tubes, the substrate was added after the heat treatment. The formation of reducing groups was estimated against $D$-glucose as the standard, after measuring the absorbance at $540 \mathrm{~nm}$.

\section{Statistical analysis}

The data represented here were statistically analysed by using SPSS 17 software. All the performed data were carried out in triplicates. Mean and S.D (Standard Deviation) were calculated. The statistical significance of the data was estimated by one-way analysis of variance and LSD test. Mean comparisons were performed using HSD of Tukey's test to scrutinise if the difference between treatments and storage time were significant at $\mathrm{P} \leq 0.05$. The overall least significance difference (LSD; $\mathrm{p} \leq 0.05$ ) was calculated and used to find significant differences among all the treatments and control set (Bico et al., 2009).

\section{Result and Discussion}

Effect of gum ghatti based edible coating emulsion on weight loss and shelf life of papaya

Weight loss of the fruits is mainly related with respiration and moisture transfer through their surface. Evaporation of water activated by a gradient of water vapour pressure at different locations in fruit is contributing to weight loss (Zhou et al., 2008).

The data presented in table 1 shows that the weight loss of all the treated, as well as control papaya fruit studied under the present study, had increased gradually all throughout the storage period. However, at the end of storage period, the lowest WLP (10.42\%) was noticed in fruit treated with T3 (gum ghatti $3 \%$, clove oil $0.1 \%$ ) and treatment $\mathrm{T} 1(13.75)$ whereas the higher WLP $(36.33 \%)$ was observed in control and fruit treated with T4gum ghatti $2 \%(24.47 \%)$. These results are in accordance with the findings of SanchezGonzalez et al., (2011) who stated that the use of fruit coatings are able to reduce weight loss at the time of storage and transportation which was mainly due to the higher water vapour resistivity of the coatings. The retardation in weight loss is due to the edible coating created a barrier on the surface of the fruit which reduces the transpiration rate. Decay is mainly caused by weight loss, not only through direct quantitative loss but also by way of the declination of appearance and textural quality. Moreover, in the present study, gum ghatti and clove oil prove their potential to extend the storage life of papaya stored at room temperature $\left(25 \pm 2{ }^{\circ} \mathrm{C}\right)$. The 
storage life of control fruits was 9 days and fruit treated with $\mathrm{T} 2$ decayed 3 days earlier (i.e. after 6 days of treatment). Whereas fruits treated with $\mathrm{T} 1$ and $\mathrm{T} 3$ could maintain their marketable acceptability till 12 days followed by $\mathrm{T} 4$ which showed storage life of 11 days. All the coating emulsions tested under the current study significantly reduced the weight loss as compared to the controls. Similar results were observed in tomato fruits treated with gum arabic coatings (Ali et al., 2010) and papaya fruits with chitosan coating (Maqbool et al., 2011). The positive effect of chitosan coating on a storage life of fruits could due to the modifying the internal atmosphere of fruits. The modified atmosphere created with edible coating that was delay the ripening by declining the ethylene production and by reducing the level of internal oxygen and consequently extending the storage life of fruit (Gol and Rao, 2011). Bosquez-Molina et al., (2010) also reported that mesquite gum coatings comprising thyme and Mexican lime oils reduced fruit decay occurrence resulting from $C$. gloeosporioides and $R$. stolonifer in papaya during storage, whereas the untreated fruit completely decayed.

\section{Effect of gum ghatti based edible coating emulsion on pH and Total Soluble Solids (TSS) of papaya}

The $\mathrm{pH}$ of treated and untreated papaya fruits increased gradually over the storage period. Baraiya et al., (2012) reported that the coating reduces respiratory and metabolic rates, and thereby the lesser utilisation of organic acids.

In the present study, the papaya fruit of the control set was found to have a higher $\mathrm{pH}$ value (i.e., 6.0) as compared with that of other treatments during a 9 day storage period. As per the data shown in table $2, \mathrm{pH}$ increased from 5.51 (at 0 day) to the highest 6.0 (at $9^{\text {th }}$ day). At the end of the storage, T1 (5.87), T3
(5.82) and T4 (5.86) treated fruits showed slightly lower $\mathrm{pH}$ than that of control (6.0) fruits. There was no statistically significant difference in the $\mathrm{pH}$ of control and treated fruits. Vyas et al., (2014) also found that the control (untreated) set of papaya fruit was found to have a higher $\mathrm{pH}$ value as compared with that of treated with the carboxymethyl cellulose (CMC) and carrageenan. These results indicate that the treated fruits could retain some level of acidity than that of the control fruit because the metabolic activities were slowed down as influenced by coating.

The level of TSS has gradually increased during their storage (Table 2). Coseteng and Lee (1987) concluded that the organic acids in papaya are mainly citric and malic acids and an increase in $\mathrm{pH}$ during ripening was due to the metabolic processes of the fruit that decreases the organic acids.

The data presented in table 2 , reveals higher TSS levels in untreated and T4 (only gum ghatti $2 \%$ ) treated fruits in comparison to that of the other treatments (i.e. T1, T2 and T3). This indicates that the edible coatings with the combination of clove oil have efficacy in delaying the process of ripening. However, at the $3^{\text {rd }}$ day of the storage period, the occurrence of higher accumulation of TSS was noticed in the control $(11 \%)$ as compared to the treated fruit.

On day 6, lower accumulation of TSS was shown in $\mathrm{T} 3(9.7 \%), \mathrm{T} 1 \quad(10 \%)$ and $\mathrm{T} 4$ $(10.3 \%)$, in contrast to $\mathrm{T} 2$ which shows highest TSS accumulation with $12 \%$ and control with $11.7 \%$. At the end of the storage period had decreased accumulation of TSS in the sets of T1 $(10 \%)$ and T3 $(10 \%)$ than that of the control (12\%). TSS of the control showed a significantly higher value during the storage, while treated fruit, except T2, show the lowest increase in TSS as storage time increases. 
The lower accumulation of TSS in coated fruit may be due to the covering of coating which reduces the rate of respiration by preventing the exchange of gases. Similar results were reported by Rahman et al., (2012) who stated that the initial TSS of all the fruits coated with chitosan and calcium chloride was low, but gradually the levels of TSS increased with ripening. Coseteng and Lee (1987) concluded that the organic acids in papaya are mainly citric and malic acids and an increase in $\mathrm{pH}$ during ripening was due to the metabolic processes of the fruit that decreases the organic acids.

\section{Effect of gum ghatti based edible coating emulsion on total sugars of papaya}

The levels of sugars gradually increase in fruits during their ripening process. Total sugars are considered good indices for the determination of storage life. An increased level of sugars was observed initially in both treated as well untreated fruits (Table 3 ).

The amount of total sugar at 0-day storage in papaya fruit was $25.3 \mathrm{mg} / \mathrm{g}$ and it increased with the period of storage. However, throughout the storage period, fruit treated with T3 and T1 significantly delayed the sugar accumulation and showed a lesser content of sugars than that of the other treatment and control fruits. At the end of the storage period (i.e. $9^{\text {th }}$ day), T1 (159.39 mg/g) and T3 (165.94 mg/g) showed lower sugar levels followed by T4 (199.72 $\mathrm{mg} / \mathrm{g})$ as compared to that of control fruits (238.17 $\mathrm{mg} / \mathrm{g}$ ). Thus it is evident from the data that here was the significantly higher value of total sugars in control, while treated fruits had least increase in total sugars during their storage.

The reasons for this significant increase may be attributed to the fact that the metabolic activities might be slow at the beginning of experiment when the fruit was in its mature stage. As the storage period increases and ripening begins which intern causes increase in the levels of sugars. Similar results were obtained by Zapata et al., (2008) who found lower sugar levels and organic acid concentrations in tomatoes coated with alginate and zein at the end of the experiment than that of the control fruits.

Effect of gum ghatti based edible coating emulsion on ascorbic acid and total phenols of papaya

Ascorbic acid is a naturally occurring organic compound with antioxidant properties. It is said to have the ability to scavenge the superoxide and hydroxyl radicals, as well as regenerate a-tocopherol (Davey et al., 2000).

The ascorbic acid content at '0'day was 57.70 $\mathrm{mg} / \mathrm{g}$, which was found to be decreasing till the end of the storage period. The obtained data from the present study showed that in all the sets of currently tested treatments, the levels of ascorbic acid contents were decreased as the storage period had increased. The decline in Ascorbic acid content from 57.70 ( 0 day) to $8.33 \mathrm{mg} / \mathrm{g}$ at the end of the storage period (Table 4), be related to its oxidation. However, the T3 and T4 treatment showed higher ascorbic acid content (19.16 $\mathrm{mg} / \mathrm{g})$ and (19.37 $\mathrm{mg} / \mathrm{g})$ respectively as compared to that of the control fruits (9.79 $\mathrm{mg} / \mathrm{g})$ and $\mathrm{T} 1(8.33 \mathrm{mg} / \mathrm{g})$. These results suggest that the edible coating used in present study helped in retaining the ascorbic acid content in papayas. Wang and Gao (2013) also found the reduced decrease of ascorbic acid in strawberries with chitosan treatments.

Fruits containing larger amounts of polyphenols are considered as significant sources of health-promoting bio-actives diet, however, the level of the phenolic contents decreased gradually during the ripening process. 
Table.1 Effect of gum ghatti based edible coating treatments on Weight Loss Percentage (WLP) of papaya fruit stored at room temperature $\left(25 \pm 2{ }^{\circ} \mathrm{C}\right)$

\begin{tabular}{|c|c|c|c|c|}
\hline \multirow{2}{*}{ Treatments } & \multicolumn{4}{|c|}{ Weight Loss \% } \\
\hline & Day 0 & Day 3 & Day 6 & Day 9 \\
\hline T1 & 0 & $0.18 \pm 0.001^{\mathrm{e}}$ & $9.53 \pm 0.000^{b}$ & $13.75 \pm 0.004^{\mathrm{c}}$ \\
\hline $\mathbf{T 2}$ & 0 & $2.44 \pm 0.003^{\mathrm{d}}$ & $8.87 \pm 0.002^{c}$ & $00.00 \pm 0.000^{\mathrm{e}}$ \\
\hline T3 & 0 & $2.66 \pm 0.001^{\mathrm{c}}$ & $6.75 \pm 0.004^{\mathrm{e}}$ & $10.42 \pm 0.001^{\mathrm{d}}$ \\
\hline $\mathbf{T 4}$ & 0 & $3.71 \pm 0.001^{b}$ & $6.84 \pm 0.001^{\mathrm{d}}$ & $24.47 \pm 0.013^{b}$ \\
\hline T5 & 0 & $8.52 \pm 0.001^{\mathrm{a}}$ & $33.49 \pm 0.006^{\mathrm{a}}$ & $36.32 \pm 0.006^{\mathrm{a}}$ \\
\hline
\end{tabular}

Table.2 Effect of gum ghatti based edible coating treatments on $\mathrm{pH}$ and Total Soluble Solids (TSS) of papaya fruit stored at room temperature $\left(25 \pm 2{ }^{\circ} \mathrm{C}\right)$

\begin{tabular}{|c|c|c|c|c|}
\hline \multirow{2}{*}{ Treatments } & \multicolumn{4}{|c|}{ pH } \\
\hline & Day 0 & Day 3 & Day 6 & Day 9 \\
\hline T1 & $5.517 \pm 0.015$ & $5.540 \pm 0.000^{c}$ & $5.793 \pm 0.021^{\mathrm{b}}$ & $5.873 \pm 0.021^{\mathrm{b}}$ \\
\hline $\mathbf{T} 2$ & $5.517 \pm 0.015$ & $4.623 \pm 0.031^{\mathrm{d}}$ & $5.787 \pm 0.015^{\mathrm{b}}$ & $0.000 \pm 0.000^{c}$ \\
\hline T3 & $5.517 \pm 0.015$ & $5.527 \pm 0.021^{\mathrm{c}}$ & $5.810 \pm 0.010^{b}$ & $5.823 \pm 0.015^{\mathrm{b}}$ \\
\hline T4 & $5.517 \pm 0.015$ & $5.740 \pm 0.020^{\mathrm{b}}$ & $5.977 \pm 0.015^{\mathrm{a}}$ & $5.867 \pm 0.099^{b}$ \\
\hline T5 & $5.517 \pm 0.015$ & $5.923 \pm 0.031^{\mathrm{a}}$ & $5.970 \pm 0.017^{\mathrm{a}}$ & $6.000 \pm 0.010^{\mathrm{a}}$ \\
\hline \multirow{2}{*}{ Treatments } & \multicolumn{4}{|c|}{ TSS (\%) } \\
\hline & Day 0 & Day 3 & Day 6 & Day 9 \\
\hline T1 & $9 \pm 0$ & $9.0 \pm 0.0^{\mathrm{d}}$ & $10.0 \pm 0.0^{b}$ & $10.0 \pm 0.0^{b}$ \\
\hline $\mathbf{T} 2$ & $9 \pm 0$ & $10 \pm 0.0^{b c}$ & $11.0 \pm 0.0^{\mathrm{a}}$ & $0.00 \pm 0.0^{c}$ \\
\hline T3 & $9 \pm 0$ & $9.3 \pm 0.6^{\mathrm{d}}$ & $09.7 \pm 0.6^{\mathrm{b}}$ & $10.0 \pm 0.0^{\mathrm{b}}$ \\
\hline T4 & $9 \pm 0$ & $10.3 \pm 0.6^{\mathrm{ab}}$ & $10.3 \pm 0.6^{\mathrm{b}}$ & $11.3 \pm 0.6^{\mathrm{a}}$ \\
\hline T5 & $9 \pm 0$ & $11.0 \pm 0.0^{\mathrm{a}}$ & $11.7 \pm 0.6^{\mathrm{a}}$ & $12.0 \pm 0.0^{\mathrm{a}}$ \\
\hline \multicolumn{5}{|c|}{$\begin{array}{l}\text { T1 (Gum ghatti } 1 \%+\text { Clove oil } 0.1 \%) \text {, T2 (Gum ghatti } 2 \%+\text { Clove oil } 0.1 \%) \text {, T3 (Gum ghatti } \\
3 \%+\text { Clove oil } 0.1 \%) \text {, T4 (Gum ghatti } 2 \% \text { ) and T5 (Control). Different letters in the same } \\
\text { column means significantly different at } \mathrm{p}<0.05 \text { using LSD. Each value is the mean for three (n } \\
=3 \text { ) replicates. }\end{array}$} \\
\hline
\end{tabular}


Table.3 Effect of gum ghatti based edible coating treatments on Total sugars of papaya fruit stored at room temperature $\left(25 \pm 2{ }^{\circ} \mathrm{C}\right)$

\begin{tabular}{|c|c|c|c|c|}
\hline \multirow{2}{*}{ Treatments } & \multicolumn{4}{|c|}{ Total sugars (mg/g) } \\
\hline & Day 0 & Day 3 & Day 6 & Day 9 \\
\hline T1 & $25.33 \pm 0.441$ & $90.44 \pm 7.26^{b}$ & $115.83 \pm 1.80^{\mathrm{a}}$ & $159.39 \pm 3.590^{c}$ \\
\hline $\mathbf{T 2}$ & $25.33 \pm 0.441$ & $87.78 \pm 3.92^{b}$ & $97.00 \pm 2.78^{b}$ & $0.000 \pm 0.000^{\mathrm{d}}$ \\
\hline T3 & $25.33 \pm 0.441$ & $68.61 \pm 9.36^{\mathrm{c}}$ & $86.11 \pm 2.14^{b}$ & $165.94 \pm 1.510^{c}$ \\
\hline T4 & $25.33 \pm 0.441$ & $88.56 \pm 6.26^{\mathrm{b}}$ & $88.28 \pm 11.90^{b}$ & $199.72 \pm 12.11^{\mathrm{b}}$ \\
\hline T5 & $25.33 \pm 0.441$ & $120.28 \pm 4.50^{\mathrm{a}}$ & $113.78 \pm 3.25^{\mathrm{a}}$ & $238.17 \pm 12.83^{\mathrm{a}}$ \\
\hline \multicolumn{5}{|c|}{$\begin{array}{l}\text { T1 (Gum ghatti } 1 \%+\text { Clove oil } 0.1 \%) \text {, T2 (Gum ghatti } 2 \%+\text { Clove oil } 0.1 \%) \text {, T3 (Gum ghatti } 3 \%+ \\
\text { Clove oil } 0.1 \%) \text {, T4 (Gum ghatti } 2 \%) \text { and T5 (Control). Different letters in the same column means } \\
\text { significantly different at } \mathrm{p}<0.05 \text { using LSD. Each value is the mean for three }(\mathrm{n}=3) \text { replicates. }\end{array}$} \\
\hline
\end{tabular}

Table.4 Effect of gum ghatti based edible coating treatments on ascorbic acid and total phenols of papaya fruit stored at room temperature $\left(25 \pm 2{ }^{\circ} \mathrm{C}\right)$

\begin{tabular}{|c|c|c|c|c|}
\hline \multirow{2}{*}{ Treatments } & \multicolumn{4}{|c|}{ Ascorbic acid (mg/g) } \\
\hline & Day 0 & Day 3 & Day 6 & Day 9 \\
\hline T1 & $57.70 \pm 1.573$ & $13.33 \pm 2.602^{\mathrm{a}}$ & $9.792 \pm 1.301^{\mathrm{c}}$ & $8.333 \pm 2.602^{b}$ \\
\hline $\mathbf{T 2}$ & $57.70 \pm 1.573$ & $12.91 \pm 1.301^{\mathrm{a}}$ & $28.95 \pm 1.804^{\mathrm{a}}$ & $0.000 \pm 0.000^{c}$ \\
\hline T3 & $57.70 \pm 1.573$ & $15.41 \pm 5.090^{\mathrm{a}}$ & $23.12 \pm 6.525^{\mathrm{ab}}$ & $19.16 \pm 2.818^{\mathrm{a}}$ \\
\hline T4 & $57.70 \pm 1.573$ & $20.83 \pm 3.969^{\mathrm{a}}$ & $21.25 \pm 2.864^{\mathrm{ab}}$ & $19.37 \pm 1.654^{\mathrm{a}}$ \\
\hline T5 & $57.70 \pm 1.573$ & $15.62 \pm 0.625^{\mathrm{a}}$ & $16.04 \pm 1.909^{b c}$ & $9.792 \pm 1.909^{b}$ \\
\hline \multirow{2}{*}{ Treatments } & \multicolumn{4}{|c|}{ Total Phenols (mg/g) } \\
\hline & Day 0 & Day 3 & Day 6 & Day 9 \\
\hline T1 & $0.753 \pm 0.023$ & $0.452 \pm 0.030^{\mathrm{a}}$ & $0.384 \pm 0.056^{\mathrm{a}}$ & $0.253 \pm 0.010^{\mathrm{ab}}$ \\
\hline $\mathbf{T 2}$ & $0.753 \pm 0.023$ & $0.434 \pm 0.010^{\mathrm{a}}$ & $0.414 \pm 0.013^{\mathrm{a}}$ & $0.000 \pm 0.000^{c}$ \\
\hline T3 & $0.753 \pm 0.023$ & $0.424 \pm 0.010^{\mathrm{a}}$ & $0.352 \pm 0.019^{\mathrm{a}}$ & $0.261 \pm 0.025^{\mathrm{ab}}$ \\
\hline T4 & $0.753 \pm 0.023$ & $0.349 \pm 0.031^{b}$ & $0.339 \pm 0.052^{\mathrm{a}}$ & $0.280 \pm 0.040^{\mathrm{a}}$ \\
\hline T5 & $0.753 \pm 0.023$ & $0.304 \pm 0.018^{\mathrm{b}}$ & $0.371 \pm 0.016^{\mathrm{a}}$ & $0.214 \pm 0.018^{\mathrm{b}}$ \\
\hline \multicolumn{5}{|c|}{$\begin{array}{l}\text { T1 (Gum ghatti } 1 \%+\text { Clove oil } 0.1 \%) \text {, T2 (Gum ghatti } 2 \%+\text { Clove oil } 0.1 \%) \text {, T3 (Gum ghatti } 3 \%+\text { Clove } \\
\text { oil } 0.1 \%), \text { T4 (Gum ghatti } 2 \%) \text { and T5 (Control). Different letters in the same column means significantly } \\
\text { different at } \mathrm{p}<0.05 \text { using LSD. Each value is the mean for three }(\mathrm{n}=3) \text { replicates. }\end{array}$} \\
\hline
\end{tabular}


Table.5 Effect of gum ghatti based edible coating treatments on total chlorophylls, lycopene and carotenoid of papaya fruit stored at room temperature $\left(25 \pm 2{ }^{\circ} \mathrm{C}\right)$

\begin{tabular}{|c|c|c|c|c|}
\hline \multirow{2}{*}{ Treatments } & \multicolumn{4}{|c|}{ Total chlorophylls $(\boldsymbol{\mu g} / \mathrm{g})$} \\
\hline & Day 0 & Day 3 & Day 6 & Day 9 \\
\hline T1 & $4.03 \pm 0.10$ & $1.98 \pm 0.15^{b}$ & $0.18 \pm 0.00^{b}$ & $0.11 \pm 0.10^{\mathrm{ab}}$ \\
\hline $\mathbf{T 2}$ & $4.03 \pm 0.10$ & $2.56 \pm 0.28^{\mathrm{a}}$ & $0.00 \pm 0.00^{c}$ & $0.00 \pm 0.00^{c}$ \\
\hline T3 & $4.03 \pm 0.10$ & $2.43 \pm 0.28^{\mathrm{ab}}$ & $0.43 \pm 0.05^{\mathrm{a}}$ & $0.35 \pm 0.10^{\mathrm{a}}$ \\
\hline T4 & $4.03 \pm 0.10$ & $0.46 \pm 0.03^{c}$ & $0.30 \pm 0.08^{\mathrm{ab}}$ & $0.22 \pm 0.17^{\mathrm{ab}}$ \\
\hline T5 & $4.03 \pm 0.10$ & $0.32 \pm 0.09^{c}$ & $0.27 \pm 0.08^{b}$ & $0.12 \pm 0.04^{\mathrm{ab}}$ \\
\hline \multirow{2}{*}{ Treatments } & \multicolumn{4}{|c|}{ Lycopene $(\mu \mathrm{g} / \mathrm{g})$} \\
\hline & Day 0 & Day 3 & Day 6 & Day 9 \\
\hline T1 & $3.354 \pm 0.046$ & $5.065 \pm 0.070^{b}$ & $5.907 \pm 0.055^{\mathrm{a}}$ & $6.588 \pm 0.063^{c}$ \\
\hline $\mathbf{T 2}$ & $3.354 \pm 0.046$ & $3.942 \pm 0.048^{\mathrm{c}}$ & $5.543 \pm 0.775^{\mathrm{a}}$ & $0.000 \pm 0.000^{\mathrm{e}}$ \\
\hline T3 & $3.354 \pm 0.046$ & $3.604 \pm 0.174^{\mathrm{d}}$ & $4.441 \pm 0.080^{\mathrm{b}}$ & $6.084 \pm 0.165^{d}$ \\
\hline $\mathbf{T 4}$ & $3.354 \pm 0.046$ & $3.593 \pm 0.113^{\mathrm{d}}$ & $4.363 \pm 0.079^{b}$ & $7.566 \pm 0.071^{\mathrm{b}}$ \\
\hline T5 & $3.354 \pm 0.046$ & $5.918 \pm 0.048^{\mathrm{a}}$ & $6.453 \pm 0.213^{\mathrm{a}}$ & $8.668 \pm 0.133^{\mathrm{a}}$ \\
\hline \multirow{2}{*}{ Treatments } & \multicolumn{4}{|c|}{ Carotenoid $(\mu g / g)$} \\
\hline & Day 0 & Day 3 & Day 6 & Day 9 \\
\hline \multirow{5}{*}{$\begin{array}{l}\text { T1 } \\
\text { T2 } \\
\text { T3 } \\
\text { T4 } \\
\text { T5 }\end{array}$} & $4.527 \pm 0.095$ & $6.567 \pm 0.204^{b}$ & $12.88 \pm 0.300^{\mathrm{c}}$ & $15.27 \pm 0.175^{\mathrm{c}}$ \\
\hline & $4.527 \pm 0.095$ & $6.073 \pm 0.114^{\mathrm{c}}$ & $15.60 \pm 0.205^{\mathrm{a}}$ & $0.000 \pm 0.000^{\mathrm{d}}$ \\
\hline & $4.527 \pm 0.095$ & $5.613 \pm 0.103^{d}$ & $8.473 \pm 0.076^{\mathrm{d}}$ & $14.70 \pm 0.964^{\mathrm{c}}$ \\
\hline & $4.527 \pm 0.095$ & $5.673 \pm 0.202^{\mathrm{cd}}$ & $9.120 \pm 0.320^{d}$ & $19.67 \pm 0.250^{b}$ \\
\hline & $4.527 \pm 0.095$ & $8.140 \pm 0.106^{\mathrm{a}}$ & $14.49 \pm 0.252^{b}$ & $22.15 \pm 0.225^{\mathrm{a}}$ \\
\hline \multicolumn{5}{|c|}{$\begin{array}{l}\text { T1 (Gum ghatti } 1 \%+\text { Clove oil } 0.1 \%) \text {, T2 (Gum ghatti } 2 \%+\text { Clove oil } 0.1 \%) \text {, T3 (Gum ghatti } 3 \%+ \\
\text { Clove oil } 0.1 \%) \text {, T4 (Gum ghatti } 2 \%) \text { and T5 (Control). Different letters in the same column means } \\
\text { significantly different at } \mathrm{p}<0.05 \text { using LSD. Each value is the mean for three }(\mathrm{n}=3) \text { replicates. }\end{array}$} \\
\hline
\end{tabular}


Table.6 Effect of gum ghatti based edible coating treatments on total antioxidant activity of Papaya fruit stored at room temperature $\left(25 \pm 2{ }^{\circ} \mathrm{C}\right)$

\begin{tabular}{|c|c|c|c|c|}
\hline \multirow{2}{*}{ Treatments } & \multicolumn{4}{|c|}{ Total antioxidant activity (\%) } \\
\cline { 2 - 5 } & Day 0 & Day 3 & Day 6 & Day 9 \\
\hline T1 & $92.98 \pm 0.494$ & $91.98 \pm 0.302^{\mathrm{b}}$ & $94.02 \pm 0.218^{\mathrm{a}}$ & $80.24 \pm 1.459^{\mathrm{b}}$ \\
T2 & $92.98 \pm 0.494$ & $92.54 \pm 0.121^{\mathrm{ab}}$ & $94.18 \pm 0.196^{\mathrm{a}}$ & $0.000 \pm 0.000^{\mathrm{c}}$ \\
T3 & $92.98 \pm 0.494$ & $92.86 \pm 0.791^{\mathrm{ab}}$ & $93.20 \pm 0.189^{\mathrm{b}}$ & $81.59 \pm 1.258^{\mathrm{b}}$ \\
T4 & $92.98 \pm 0.494$ & $93.52 \pm 0.104^{\mathrm{a}}$ & $92.17 \pm 0.574^{\mathrm{c}}$ & $87.59 \pm 0.547^{\mathrm{a}}$ \\
T5 & $92.98 \pm 0.494$ & $93.34 \pm 0.218^{\mathrm{a}}$ & $92.48 \pm 0.054^{\mathrm{bc}}$ & $87.41 \pm 0.933^{\mathrm{a}}$ \\
\hline T1 (Gum ghatti $1 \%+$ Clove oil 0.1\%), T2 (Gum ghatti 2\% Clove oil 0.1\%), T3 (Gum ghatti $3 \%+$ \\
Clove oil 0.1\%), T4 (Gum ghatti 2\%) and T5 (Control). Different letters in the same column means \\
significantly different at p $<0.05$ using LSD. Each value is the mean for three $(n=3)$ replicates \\
\hline
\end{tabular}

Figure.1 Effect of gum ghatti based edible coating treatments on activity of PG of papaya fruit stored at room temperature $\left(25 \pm 2{ }^{\circ} \mathrm{C}\right)$

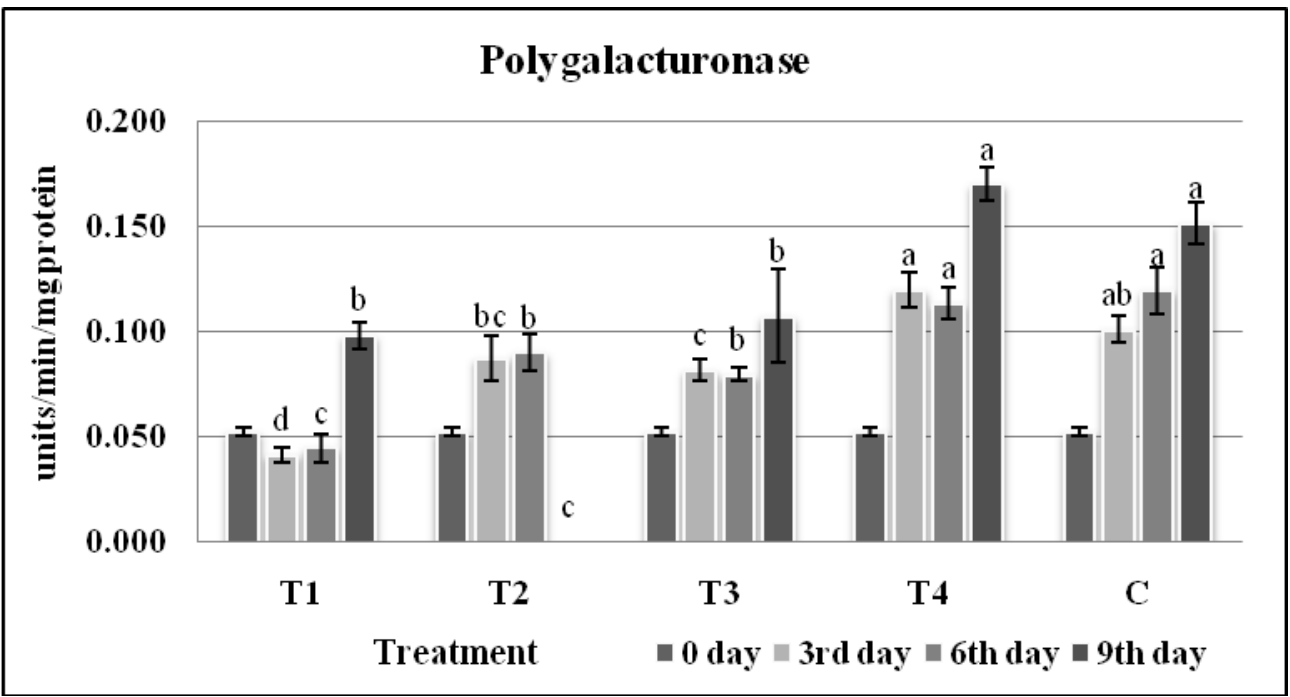

Figure.2 Effect of gum ghatti based edible coating treatments on activity of cellulase of papaya fruit stored at room temperature $\left(25 \pm 2{ }^{\circ} \mathrm{C}\right)$

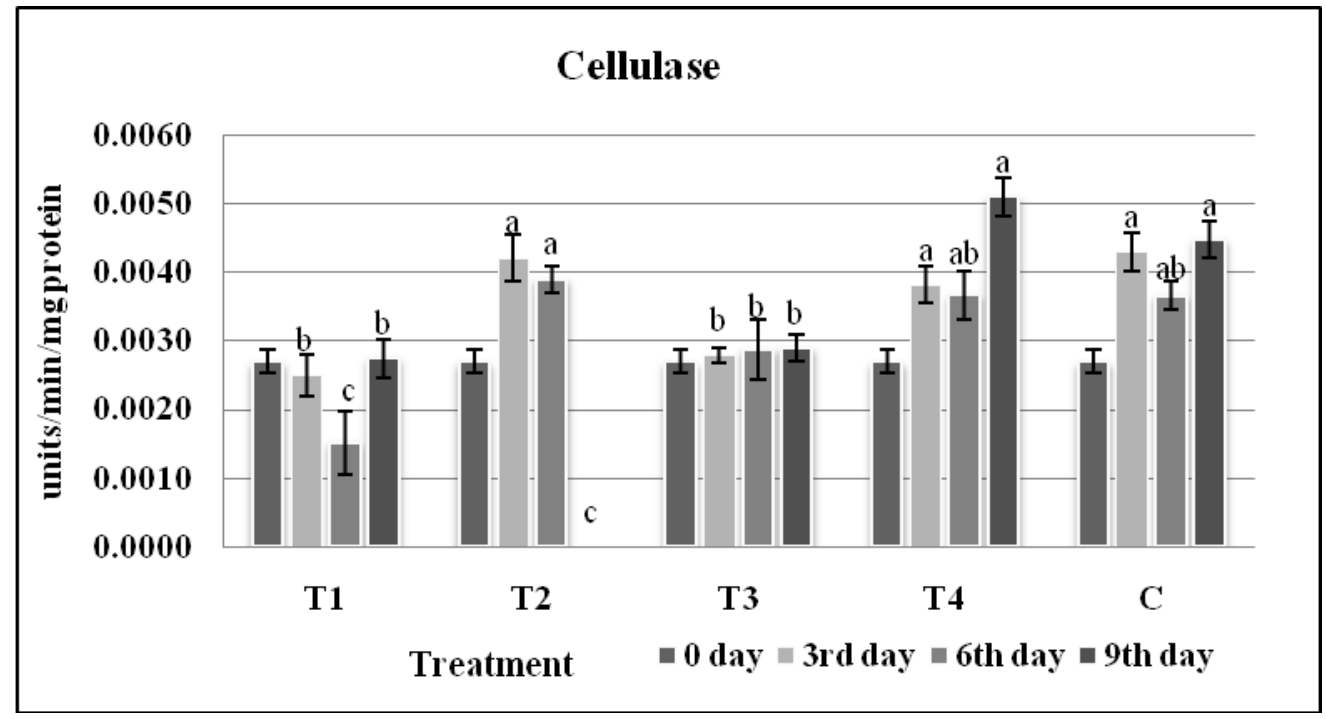


Effect of gum ghatti based edible coating emulsion on total chlorophylls, carotenoids and lycopene of papaya

Important criteria of quality and consumer acceptability of papaya fruits are its colour. During the ripening of fruits, the colour of fruits changes due to the degradation of chlorophyll and the simultaneous synthesis of other pigments like carotenoids and lycopene. A pigmentation change in the final stages of papaya fruit ripening is mainly due to the Chlorophyll degradation (Azevedo et al., 2008).

The levels of chlorophyll content of presently studied papaya fruits decreased gradually during its ripening. Initially, on 0 -day the total chlorophyll value was $4.03 \mu \mathrm{g} / \mathrm{g}$, which had decreased gradually till the $9^{\text {th }}$ day $(0.11 \mu \mathrm{g} / \mathrm{g})$ (Table 5). However, at the end of the storage period, a higher level of photosynthetic pigments was noticed in $\mathrm{T} 3(0.35 \mu \mathrm{g} / \mathrm{g})$ and $\mathrm{T} 2(0.22 \mu \mathrm{g} / \mathrm{g})$ treatments and the lower level was recorded in $\mathrm{T} 1(0.11 \mu \mathrm{g} / \mathrm{g})$ and control fruits $(0.12 \mu \mathrm{g} / \mathrm{g})$. Mejia-Toress et al., (2009) reported that the use of wax as coating material cause delaying of chlorophyll degradation.

The level of carotenoids and lycopene gradually increased during the ripening of fruits. The higher level of these pigments indicates a higher rate of ripening in the fruit which could be observed more in control than in the treated fruits. In the present study, the higher levels of both these pigments were found at the end of the storage period in control fruits as compared to the treated fruits (Table 5).

During ripening, while the amount of chlorophyll in fruit tissues decreases quickly, the amount of carotenoids increases (Merzlyak et al., 1999). Initially, on 0 day the levels of carotenoid were $4.52 \mu \mathrm{g} / \mathrm{g}$ and it had increased with the storage period in treated and control fruits. The higher levels of carotenoids $(8.14 \mu \mathrm{g} / \mathrm{g})$ were noticed in the fruits of control set as compared to that of $\mathrm{T} 1$ $(6.56 \mu \mathrm{g} / \mathrm{g}), \mathrm{T} 2(6.07 \mu \mathrm{g} / \mathrm{g}), \mathrm{T} 3(5.61 \mu \mathrm{g} / \mathrm{g})$ and $\mathrm{T} 4(5.67 \mu \mathrm{g} / \mathrm{g})$. At the end of the storage period, the higher level of carotenoids $(22.15 \mu \mathrm{g} / \mathrm{g})$ are found to occur in control fruits and lower level of it $(14.70 \mu \mathrm{g} / \mathrm{g})$ was observed in $\mathrm{T} 3$ and other treated fruits. These results presented in table 5 indicate that the control fruits had a higher rate of carotenoid synthesis as compared with that of the treated fruits which show a lower rate of carotenoid synthesis. Significantly, T3 and T4 treatments show the slower rate of carotenoid synthesis that indicates that there was a delay in the ripening process, thus retain the pigments.

At the end of the storage period, the lycopene level was found higher in control papaya fruit $(8.6 \mu \mathrm{g} / \mathrm{g})$ as compared to that in $\mathrm{T} 1(6.5 \mu \mathrm{g} / \mathrm{g})$ and T3 $(7.5 \mu \mathrm{g} / \mathrm{g})$. Likewise, the level of lycopene synthesis was higher in fruits of control set than that of treated fruits. The results of lycopene level observed from table 5 indicate that the rate of synthesis of lycopene was higher in control fruits with compared to that treated fruits. There was a significantly higher amount of carotenoid and lycopene observed in control fruits in comparing with that of the fruits of experimental sets (T1 to $\mathrm{T} 4$ ) fruits during their storage period.

These results indicate that the edible coatings could delay the ripening with the retention of the pigment in treated fruits. The delay in the ripening of the coated fruit may be due to the modified internal atmosphere in the coated fruit that reduces the degradation of chlorophylls and/or the biosynthesis of carotenoids and lycopene (Carrillo-Lopez et al., 2000). Wills and Widjanarko, (1995) reported that the chlorophyll depletion involved at the final stage of papaya fruit 
ripening and the biosynthesis of carotenoids that resulting in changes of colour from green to yellowish-orange and red.

\section{Effect of gum-ghatti based edible coating emulsion on total antioxidant activity}

On ' 0 '-day the total antioxidant activity was $92.98 \%$. However, on $3^{\text {rd }}$ day control $(93.34 \%)$ and T4 (93.52\%) fruits showed higher antioxidant activity as compared to that of T1, T2 and T3 which showed $91.98 \%$, $92.54 \%, 92.86 \%$, respectively. At the end of storage not much significant difference was observed in antioxidant activity from 0-day, however, the control and T4 showed higher activity $87.41 \%$ and $87.59 \%$ respectively than that of T1 $(80.24 \%)$ and T3 $(81.41 \%)$. The result from table 6 indicates that the antioxidant activity was lower in the fruits of experimental sets with clove oil as compared to the control and only gum ghatti (2\%) coated fruits at the end of storage period.

\section{Effect on softening related enzymes}

Pectins are cell wall polysaccharides that are soluble in water so that they can be deesterified and depolymerised mostly by enzymatic reactions. Polygalacturonase (PG) catalyses the hydrolysis of demethylated pectins and causes depolymerisation and dissolution of pectins (Singh and Dwivedi, 2008). PG is responsible for ripening associated pectin modifications, contributing to fruit softening. In the current study, the specific activity of PG increased gradually due to the continuous softening process in the papaya fruit during their storage in both treated as well as control set.

The results of the current study further reveal that initially (at 0 day), the activity of PG was low $(0.053 \mathrm{U} / \mathrm{mg}$ proteins $)$, but subsequently it increased and reached to its peak on the $9^{\text {th }}$ day of storage (Fig. 1). On the $3^{\text {rd }}$ day of storage, the higher activity of PG was found in $\mathrm{T} 4(0.120 \mathrm{U} / \mathrm{mg}$ proteins $)$ and control fruit $(0.101 \mathrm{U} / \mathrm{mg}$ proteins $)$, while the reduced activity was found in the fruits treated with T1 (0.042 U/mg proteins), T2 $(0.087 \mathrm{U} / \mathrm{mg}$ proteins) and T3 (0.082 U/mg proteins). At the end of the storage period, the activity of PG was lower in the fruits treated with T1 $(0.098 \mathrm{U} / \mathrm{mg}$ proteins) and T3 $(0.107 \mathrm{U} / \mathrm{mg}$ proteins) in comparison with that of $\mathrm{T} 4$, while control i.e. $0.170 \mathrm{U} / \mathrm{mg}$ proteins and 0.152 U/mg proteins respectively (Fig. 1). There was a significantly higher activity of PG in T4 and control, while other treatments showed the lowest increase in PG activity. Baraiya et al., (2016) found during their study that the specific activity of PG increased gradually due to the continuous softening process in Ber fruit.

In the present study, as the ripening of fruit is increasing the cellulase activity also get increased. The lower activity of cellulase was observed in treated fruit with the addition of clove oil, except in T4 treatment as compared to that of the control fruit (Fig. 2). On 0-day, the cellulase activity was $0.0027 \mathrm{U} / \mathrm{mg}$ proteins, which gradually increased in treated and control fruits during the storage period. On $3^{\text {rd }}$ day the cellulase activity observed in T1 was in decreased level and then it get increased in other treatments and control, control (0.043 U/mg proteins) and T4 (0.0038 $\mathrm{U} / \mathrm{mg}$ proteins) showed higher cellulase activity than the $\mathrm{T} 1(0.0025 \mathrm{U} / \mathrm{mg}$ proteins $)$, T2 (0.0042 U/mg proteins), T3 $(0.0028 \mathrm{U} / \mathrm{mg}$ proteins). At the end of the storage, T4 and control sets showed highest cellulase activity $0.0051 \mathrm{U} / \mathrm{mg}$ proteins and 0.0045 respectively as compared to the T1 $(0.0027 \mathrm{U} / \mathrm{mg}$ proteins), T3 $(0.0029 \mathrm{U} / \mathrm{mg}$ proteins $)$. These results indicate that the treatments $\mathrm{T} 1, \mathrm{~T} 2$ and T3 (gum ghatti + clove oil) show lower cellulase activity than in control and T4 (gum ghatti $2 \%$ ) treatment. 
Yadav et al., (2012) also found that the activities of cell wall softening related enzymes in Ber fruit increased linearly during ripening. Significant effects were observed for all gum ghatti and clove oil treatments (T1, T2 and T3) in terms of softening related enzymes polygalacturonase (PG) and cellulase.

In conclusion the present study revealed that the currently tested coating solutions of gum ghatti and clove oil were effective in improving the shelf life and quality of papaya fruits. These coatings reduced the decay, weight loss, augmentation of total soluble solids (TSS) and total sugars by controlling the rate of respiration and metabolic activities in treated fruits. These coatings influence the chlorophyll degradation by slowing the rate of degradation and retained the level of antioxidants in treated fruits as compared to that of control fruits. Lycopene and carotenoid levels were higher in control fruits, so it may be interpreted that these coatings could slow down the synthesis of lycopene and carotenoid in treated fruits and retention of the significant amount of these pigments in the fruits of experimental sets which is important for the antioxidant property of fruit. The delayed activities of polygalacturonase (PG) and cellulase were noticed in fruit coated with the sets gum ghatti with clove oil as compared to that of other treatments and control sets, that demonstrating the reduced softening and ripening process. These findings suggest that these coating solutions tested under current study have the potential to control decaying prevalence and extends the storage life of papaya up to 12days, while the control papayas were decayed on the $9^{\text {th }}$ day.

\section{Acknowledgements}

The authors are grateful to the Head, P.G. Department of Biosciences, Sardar Patel
University, Gujarat, India, for providing the necessary facilities for carrying out this work.

\section{References}

A.O.A.C. (Association of Official Analytical Chemists) 1994. Official method of analysis (16th ed.), Association of official analytical chemist: Virginia, U.S.A.

Ali, A., Maqbool, M., Ramachandran, S., Alderson, P.G. 2010. Gum arabic as a novel edible coating for enhancing shelf-life and improving postharvest quality of tomato (Solanum lycopersicum L.) fruit. Postharvest Biol. Technol., 58: 42-47.

Archbold, D., Koslanund, R. and Pomper, K. 2003. Ripening and postharvest storage of pawpaw. Hort. Technol., 13(3): 439-441.

Azevedo, I.G., Oliveira, J.G., da Silva, M.G., Pereira, T., Corrêa, S.F., Vargas, H., Facanha, A.R. 2008. P-type H + -ATPases activity, membrane integrity, and apoplastic $\mathrm{pH}$ during papaya fruit ripening. Postharvest Biol. Technol., 48: 242-247.

Bamdad, F., Kadivar, M., Keramat, J. 2006. Evaluation of phenolic content and antioxidant activity of Iranian caraway in comparison with clove and BHT using model systems and vegetable oil. Int. J. Food Sci. Technol., 41(1): S20-S27.

Baraiya, N.S., Gol, N.B. and Ramana Rao, T.V. 2012. Influence of polysaccharide based edible coatings on the shelf life and nutritional quality of tomato fruit. Food Global Sci. Book, 6(1): 22-27.

Baraiya, N.S., Ramana Rao, T.V. and Thakkar, V.R. 2016. Composite coating as a carrier of anti-oxidents improves the post harvest shelf life and quality of table grapes (Vitis vinifera L. var. Thompson seedless). J. Agri. Sci. Technol., 18: 93-107.

Bico, S.L.S., Raposo, M.F.J., Morais, R.M.S.C. and Morais, A.M.M.B. 2009. Combined effects of chemical dip and/or carrageenan coating and/or controlled atmosphere on quality of fresh cut banana. J. Food Control, 20: 508-514.

Bosquez-Molina, E., Ronquillo-de Jesús, E., Bautista-Baños, S., Verde-Calvo, J.R. and Morales-López, J. 2010. Inhibitory effect of 
essential oils against Colletotrichum gloeosporioides and Rhizopus stolonifer in stored papaya fruit and their possible application in coatings. Postharvest Biol. Technol., 57(2): 132-137.

Brishti, F.H., Misira, J. and Sarkera, A. 2013. Effect of Bio-preservatives on storage life of papaya (Carica papaya L.). Int. J. Food Studies IJFS, 2: 126-136.

Carrillo-Lopez, A., Ramirez-Bustamante, F., Valdez-Torres, B., Rojas-Villegas, R., Yahia, M. 2000. Ripening and quality changes in mango fruit as affected by coating with an edible film. J. Food Quality, 23(5): 479-486.

Castellani, O., Gaillard, C., Vie, V., Al-Assaf, S., Axelos, M. and Phillips, G.O. 2010. Hydrocolloids with emulsifying capacity. Food Hydrocolloids, 24(2-3): 131-141.

Coseteng, M.Y. and Lee, C.Y. 1987. Changes in apple polyphenoloxidase (PPO) and polyphenol concentrations in relation to degree of browning. J. Food Sci., 52: 985989.

Davey, M.W., Van Montagu, M., Inze, D., Sanmartin, M., Kanellis, A., Smirnoff, N. 2000. Plant L-ascorbic acid: chemistry, function, metabolism, bioavailability and effects of processing. J. Sci. Food and Agri., 80: 825-860.

Gol, N.B., Rao, T.V.R. 2011. Banana fruit ripening as influenced by edible coatings. Int. J. Fruit Sci., 11: 119-135.

Jayathunge, K., Prasad, H., Fernando, M., and Palipane, K. 2011. Prolonging the postharvest life of papaya using modified atmosphere packaging. J. Agri. Technol., 7(2): 507-518.

Lohani, S., Trivedi, P.K., and Nath, P. 2004. Changes in activities of cell wall hydrolases during ethylene-induced ripening in banana: effect of 1-MCP, ABA and IAA. Postharvest Biol. Technol., 31: 119-126.

Lowry, O.H., Rosebrough, N.J., Farr, A.L., Randall, R.J. 1951. Protein measurement with the folin phenol reagent. J. Biol. Chem., 193: 265-275.

Maqbool, M., Ali, A., Alderson, P.G., Mohamed, M.T.M., Siddiqui, Y., Zahid, N. 2011. Postharvest application of gum Arabic and essential oils for controlling anthracnose and quality of banana and papaya during cold storage. Postharvest Biol. Technol., 62: 71-76.

Mejia-Torres, S., Vega-Garcia, M., ValverdaJuarez, J., Lopez-Valenzuela, J., and CaroCorrales, J. 2009. Effect of wax application on the quality, lycopene content and chilling injury of tomato fruit. J. Food Quality, 32(6): 735-746.

Meng, X., Boqiang, L., Liu, J., and Shiping, T. 2008. Physiological responses and quality attributes of table grape fruit to chitosan pre-harvest spray and postharvest coating during storage. Food Chem., 106: 501-508.

Merzlyak, M.N., Gitelson, A.A., Chivkunova, O.B., Rakitin, V.Y. 1999. Non-destructive optical detection of pigment changes during leaf senescence and fruit ripening. Physiol. Plant, 106: 135-141.

Mondal, M.F. 2000. Production and storage of fruits (in Bangla), published by Mrs. Afia Modal, BAU Campus, Mymensingh-2202: 312

Oms-Oliu, G., Rojas-Graü, M.A., González, L.A., Varela, P., Soliva-Fortuny, R., Hernando, M.I.H., Munuera, I.P., Fiszman, S., and Martín-Belloso, O. 2010. Recent approaches using chemical treatments to preserve quality of fresh-cut fruit: A review. Postharvest Biol. Technol., 57: 139-148.

Park, H.J. 1999. Development of advanced edible coatings for fruits. Trend in Food Sci. Technol., 10(8): 254-260.

Pathak, N., and Sanwal, G.G. 1998. Multiple forms of polygalcturonase from banana fruits. Phytochem., 48: 249-255.

Rahman, M.A., Mahmud, T.M.M., Abdul Rahman, R., Kadir, J. and Begum, M.M. 2012. Potential co-application of burkholderia cepacia, calcium and chitosan on enhancement of storage life and quality of papaya fruits. Pertanika J. Trop. Agri. Sci., 35(3): 439-458.

Roe, J. 1954. Chemical determination of ascorbic acids. Methods of Biochem. Analysis, 1: 115.

Sadasivam, S., and Manickam, A. 1992. Biochemical methods for agricultural sciences, Wiley Eastern Ltd, New Delhi. Pp 12-13.

Sánchez-González, L., Pastor, C., Vargas, M., 
Chiralt, A., González-Martínez, C., Cháfer, C. 2011. Effect of hydroxypropylmethyl cellulose and chitosan coatings with and without bergamot essential oil on quality and safety of cold stored grapes. Postharvest Biol. Technol., 60: 57-63.

Sanchez-Moreno, C., Cao, G., Ou, B., and Prior, R.L. 2003. Anthocyanin and proanthocyanidin content in selected white and red wines. Oxygen radical absorbance capacity comparison with nontraditional wines obtained from highbush blueberry. $J$. Agri. Food Chem., 51(17): 4889-4896.

Singh, P., and Dwivedi, U.N. 2008. Purification and characterisation of multiple forms of polygalacturonase from mango (Mangifera indica cv. Dashehari) fruit. Food Chem., 111(2): 345-349.

Thimmaiah, S.K. 1999. Standards methods of Bio-chemical analysis, Kalyani publication, New Delhi, India.

Velickova, E., Winkelhausen, E., Kuzmanova, S., Alves, V.D., and Moldao-Martins, M. 2013. Impact of chitosan-beeswax edible coatings on the quality of fresh strawberries (Fragaria ananassa cv Camarosa) under commercial storage conditions. LWT: Food Sci. Technol., 52: 80-92.

Vyas, P.B., Gol, N.B and Rao, T.V.R. 2014. Postharvest Quality Maintenance of Papaya Fruit Using Polysaccharide-Based Edible Coatings. Int. J. Fruit Sci., 14(1): 81-94.

Wang, L.Z., Liu, L., Holmes, J., Kerry, J.P. 2007. Assessment of film forming potential and properties of protein and polysaccharidebased biopolymer films. Int. J. Food Sci. Technol., 42(9): 1128-1138.

Wang, S.Y., and Gao, H. 2013. Effect of chitosanbased edible coating on antioxidants, antioxidant enzyme system, and postharvest fruit quality of strawberries (Fragaria $\mathrm{x}$ aranassa Duch.). LWT: Food Sci. Technol., 52: 71-79.

Wills, R.B.H., Widjanarko, S.B. 1995. Changes in physiology, composition and sensory characteristics of Australian papaya during ripening. Australian J. Experimental Agri., 35: 1173-1176.

Yadav, P., Kumar, S., Jain, V., and Malhotra, S.P. 2012. Cell wall metabolism of two varieties of ber (Ziziphus mauritiana Lam.) fruit during ripening. Food Technol. Biotechnol., 50(4): 467-472.

Zapata, P.J., Guille, F., Martinez-Romero, D., Castillo, S., Valero, D., Serrano, M. 2008. Use of alginate or zein as edible coatings to delay postharvest ripening process and to maintain tomato (Solanum lycopersicon Mill) quality. J. Sci. Food and Agri., 88: 1287-1293.

Zhou, R., Yun, M., Li, Y., Yanyun, Z., Zhang, G., and Yunsheng, H. 2008. Quality and internal characteristics of Huanghua pears (Pyrus pyrifolia Nakai, cv. Huanghua) treated with different kinds of coatings during storage. Postharvest Biol. Technol., 49: 171-179.

\section{How to cite this article:}

Arpit V. Joshi, Nilanjana S. Baraiya, Pinal B. Vyas and Ramana Rao, T.V. 2017. Gum Ghatti Based Edible Coating Emulsion with an Additive of Clove Oil Improves the Storage Life and Maintains the Quality of Papaya (Carica papaya L., cv. Madhu bindu). Int.J.Curr.Microbiol.App.Sci. 6(5): 160-174. doi: http://dx.doi.org/10.20546/ijcmas.2017.605.019 